\title{
PENGARUH KOMPENSASI, GAYA KEPEMIMPINAN DAN KARAKTERISTIK TENAGA PEMASAR TERHADAP MOTIVASI DAN KINERJA TENAGA PEMASAR PADA PT. BANK RAKYAT INDONESIA (PERSERO) Tbk. CABANG JOMBANG
}

\author{
Mokhamad Yanuar Pradita \\ Program Magister Manajemen, Universitas Muhammadiyah Malang \\ Email: yanzpradita88@gmail.com
}

\begin{abstract}
The purpose of this research is to know: 1) the effect of compensation on work motivation, 2) the influence of leadership style on work motivation, 3) influence of marketer's characteristic to work motivation, 4) influence of work motivation to marketer performance, 5) influence of compensation to performance marketers, 6) influence of marketer's characteristic on sales force performance, 7) influence of leadership style on marketer's performance, 8) influence of compensation to marketer's performance through motivation, 9) influence of leadership style on marketer's performance through motivation, the characteristics of marketers to marketers' performance through motivation. The sample of the study was 136 respondents taken with purposive sampling technique. Data analysis technique is done by SEM analysis.

The results of this study are as follows: 1) Compensation has a significant negative effect on work motivation. 2) Characteristics of individual marketers have a significant positive effect on work motivation. 3) Leadership style has a significant positive effect on work motivation. 4) Motivation has a significant positive effect on performance. 5) Compensation has a significant negative effect on performance. 6) Characteristics of individual marketers have a significant positive effect on performance. 7) Leadership style has a significant positive effect on performance. 8) Work motivation mediates between compensation for performance. 9) Work motivation mediates between leadership styles on performance. 10) Work motivation mediates between the individual characteristics of the marketer's force on performance.
\end{abstract}

Keywords: Compensation, Leadership Style, Individual Characteristics, Work Motivation, Performance.

\begin{abstract}
Abstrak: Tujuan penelitian ini adalah untuk mengetahui: 1) pengaruh kompensasi terhadap motivasi kerja, 2) pengaruh gaya kepemimpinan terhadap motivasi kerja, 3) pengaruh karak-teristik tenaga pemasar terhadap motivasi kerja, 4) pengaruh motivasi kerja terhadap kinerja tenaga pemasar, 5) pengaruh kompensasi terhadap kinerja tenaga pemasar, 6) pengaruh karak-teristik tenaga pemasar terhadap kinerja tenaga pemasar, 7) pengaruh gaya kepemimpinan terhadap kinerja tenaga pemasar, 8) pengaruh kompensasi terhadap kinerja tenaga pemasar mela-lui motivasi, 9) pengaruh gaya kepemimpinan terhadap kinerja tenaga pemasar melalui motivasi, 10) pengaruh karakteristik tenaga pemasar terhadap kineja tenaga pemasar melalui motivasi. Sampel penelitian sebanyak 136 responden yang diambil dengan teknik sampling purposive. Teknik analisis data dilakukan dengan SEM analysis.

Hasil penelitian ini adalah sebagai berikut: 1) Kompensasi berpengaruh signifikan negatif terhadap motivasi kerja. 2) Karakteristik individu tenaga pemasar berpengaruh signifikan positif terhadap motivasi kerja. 3) Gaya kepemimpinan berpengaruh signifikan positif terhadap motivasi kerja. 4) Motivasi berpengaruh signifikan positif terhadap kinerja. 5) Kompensasi berpengaruh secara signifikan negatif terhadap kinerja. 6) Karakteristik individu tenaga pemasar berpengaruh signifikan positif terhadap kinerja. 7) Gaya kepemimpinan berpengaruh signifikan positif terhadap kinerja. 8) Motivasi kerja memediasi antara kompensasi terhadap kinerja. 9) Motivasi kerja memediasi antara gaya kepemimpinan terhadap kinerja. 10) Motivasi kerja memediasi antara karakteristik individu tenaga pemasar terhadap kinerja.
\end{abstract}

Kata Kunci: Kompensasi, Gaya Kepemimpinan, Karakteristik Individu, Motivasi kerja, Kinerja. 
Pada era globalisasi seperti sekarang ini, perusahaan dituntut mampu bersaing secara profesional. Salah satu strategi penting yang dapat dilakukan perusahaan untuk dapat bersaing dengan pengelolaan sumber daya manusia. Sumber daya manusia merupakan kekuatan dalam keberhasilan suatu organisasi atau perusahaan, khususnya perusahaan yang bergerak dibidang perbankan, peran tenaga pemasar (marketers) dalam meningkatkan pertumbuhan kredit perbankan. Perusahaan perlu melakukan strategi untuk mengoptimalkan pengelolaan sumber daya manusia agar menghasilkan sumber daya manusia yang kompeten sehingga nantinya dapat meningkatkan kinerja karyawan khususnya tenaga pemasar dan kinerja perusahaan.

Salah satu strategi yang dilakukan perusahaan untuk meningkatkan motivasi dan kinerja tenaga pemasar yaitu dengan pemberian reward atau kompensasi kerja. Kompensasi merupakan kebijaksanaan dalam suatu organisasi yang penting dan strategis karena hal ini langsung berhubungan dengan peningkatan semangat kerja, kinerja karyawan dalam suatu perusahaan. Pemberian kompensasi sangat penting bagi karyawan, karena besar kecilnya kompensasi merupakan ukuran terhadap prestasi kerja karyawan. Apabila sistem kompensasi yang diberikan perusahaan cukup adil, maka karyawan khususnya tenaga pemasar dapat bekerja lebih produktif dan meningkatkan tanggung jawab dalam melaksanakan tugas yang diberikan perusahaan. Oleh karena itu kompensasi merupakan faktor yang penting untuk memotivasi karyawan dalam meningkatkan kinerjanya.

Motivasi merupakan salah satu faktor yang mendorong seseorang untuk melakukan suatu aktivitas tertentu. Murty dan Hundiwinarsih (2012) menyatakan bahwa seorang karyawan yang termotivasi akan bersifat energik dan bersemangat, dan sebaliknya seorang karyawan dengan motivasi yang rendah akan sering menampilkan rasa tidak nyaman dan tidak senang terhadap pekerjaannya yang mengakibatkan kinerja mereka menjadi buruk dan tujuan perusahaan tidak akan tercapai. Motivasi kerja karyawan salah satunya disebabkan oleh pemberian kompensasi yang sesuai. Jika kompensasi lebih diperhatikan oleh perusahaan maka, diharapkan keahlian dan motivasi kerja yang dimiliki tenaga pemasar dapat meningkat sehingga juga berpengaruh terhadap meningkatnya kinerja tenaga pemasar.
Karakteristik atau faktor personal tenaga pemasar juga berpengaruh terhadap kinerja dan motivasi tenaga pemasar. Karakteristik individu merupakan sikap atau perilaku seseorang dalam menjalankan tugas yang diberikan dimana sikap dan perilaku tersebut berpengaruh terhadap kinerjanya. Seorang pemimpin harus mengetahui karakteristik tenaga pemasarnya agar dapat dengan mudah mengarahkan dan memotivasinya dalam bekerja. Oleh karena itu gaya kepemimpinan seorang pemimpin akan sangat berpengaruh terhadap peningkatan kinerja dan motivasi tenaga pemasar. Pemimpin akan mempengaruhi komitmen organisasional dan kinerja karena mereka dapat memimpin karyawan untuk mencapai hasil dari tujuan organisasi (Yeh dan Hong, 2012).

Penelitian ini akan mencoba untuk mengetahui seberapa besar pengaruh kompensasi, gaya kepemimpinan, dan karakteristik tenaga pemasar terhadap motivasi dan kinerja tenaga pemasar. Tenaga pemasar menempati ujung tombak di bidang perbankan terutama dalam kegiatan penyaluran kredit. Peran tenaga pemasar dalam meningkatkan pertumbuhan penjualan telah lama menjadi salah satu strategi pemasaran. Salah satu perusahaan di Indonesia yang sangat memperhatikan perihal motivasi dan kinerja karyawannya adalah PT. Bank Rakyat Indonesia (Persero) Tbk.

PT. Bank Rakyat Indonesia (Persero) Tbk. merupakan perusahaan BUMN yang bergerak dibidang perbankan. Pendapatan bank yang diperoleh dari sektor perkreditan merupakan sumber pendapatan terbesar dibandingkan dengan jumlah pendapatan yang diperoleh dari sektor lainnya. Sektor perkreditan pada perbankan dianggap sebagai sektor yang vital. Pada perbankan untuk memperoleh pendapatan besar dari bunga kredit diperlukan kinerja penyaluran kredit yang baik sehingga laju pertumbuhan kredit bisa meningkat dengan tingkat produktivitas yang optimal. Kinerja penyaluran kredit adalah menyangkut seluruh proses pemberian kredit yang dilakukan perbankan kepada masyarakat dan menyangkut hasil perolehan dari pemberian kredit serta resiko yang timbul dari penyaluran kredit tersebut.

Pihak manajemen akan melakukan penilaian untuk menjaga laju pertumbuhan kredit yang baik dengan membandingkan hasil yang diperoleh dengan target yang ditentukan. Perbandingan hasil yang dilakukan pada setiap 
periodenya akan terlihat kinerja mana yang nilainya lebih baik. Pada penyaluran kredit bisnis mikro, yang menjadi sasaran penyalurannya adalah sektor Usaha Kecil Menengah. Penyaluran kredit pada bisnis mikro banyak dilakukan oleh PT. Bank Rakyat Indonesia (Persero) Tbk. Keseriusan dalam penyaluran kredit mikro yang dilakukan tidak perlu diragukan lagi. PT. Bank Rakyat Indonesia (Persero) Tbk. masih menjadi bank dengan penyaluran kredit mikro terbesar dibandingkan dengan bank lain. Keberhasilan tersebut didukung banyaknya BRI Unit yang dibuka hampir pada setiap kecamatan.

Berdasarkan keadaan tersebut maka sangat diperlukan Sumber Daya Manusia (SDM) khususnya tenaga pemasar yang mendukung dalam kegiatan penyaluran kredit. Diperlukan tenaga-tanaga pemasar yang dapat melakukan ekspansi kredit secara maksimal sesuai target yang sudah ditentukan perusahaan. Selain itu upaya untuk mendukung kinerja dan motivasi tenaga pemasar agar bisa bekerja maksimal sesuai dengan target yang telah ditentukan, maka perusahaan perlu memberikan insentif sebagai kompensasi kepada tenaga pemasar. Pernyataan ini diperkuat oleh hasil penelitian Mphil et al. (2014) dan Negash et al. (2014) yang menyebutkan bahwa kompensasi dan komponennya seperti payment, promotion, recognition, working condition and benefit berpengaruh positif pada kinerja dan motivasi karyawan.

Selain pemberian kompensasi, salah satu yang berpengaruh terhadap peningkatan kinerja dan motivasi tenaga pemasar yaitu karakteristik individu tenaga pemasar dan gaya kepemimpinan unit kerja. Hasil penelitian Cherian dan Jacob (2013); Gopal dan Chowdhury (2014) memperkuat pernyataan tersebut yaitu karakteristik individu yang berupa self-efficacy dan gaya kepemimpinan dapat memotivasi dan meningkatkan kinerja karyawan. Penerapan gaya kepemimpinan yang berbeda akan memiliki pengaruh terhadap motivasi karyawan yang berbeda.

\section{KAJIAN PUSTAKA}

Kompensasi adalah seluruh balas jasa baik berupa uang, barang ataupun kenikmatan yang diberikan oleh perusahaan kepada karyawan atas kinerja yang disumbangkan kepada perusahaan (Kadarisman, 2012). Kompensasi merupakan kebijaksanaan dalam suatu organisasi yang penting dan strategis karena hal ini berhubungan langsung dengan peningkatan semangat kerja, kinerja karyawan dalam suatu perusahaan. Tujuan manajemen kompensasi adalah untuk membantu perusahaan mencapai tujuan keberhasilan strategi perusahaan dan menjamin terciptanya keadilan eksternal dan internal (Mondiani, 2012).

Kepemimpinan juga mempengaruhi karyawan untuk secara sukarela mengejar tujuan organisasi (Kreitner dan Kinicki, 2005). Gaya kepemipinan menurut Brown (2014) diasumsikan sebagai penerapan gaya tertentu, sikap atau perilaku yang akan mengubah pemimpin dan menciptakan perilaku baru dari pemimpin sehingga menjadi lebih efektif. Pemimpin yang efektif menerapkan gaya kepemimpinannya harus memahami terlebih dahulu karakteristik individu bawahannya, mengerti kekuatan dan kelemahan bawahannya, dan mengerti bagaimana caranya memanfaatkan kekuatan bawahan untuk mengimbangi kelemahan yang mereka miliki.

Karakteristik individu adalah sesuatu yang dimiliki oleh seseorang yang didalamnya terdiri dari demografi karakteristik variabel, kemampuan, dan kepribadian (Robbins dan Judge, 2008). Thoha (2004) mengatakan bahwa karakter individu merupakan sikap atau perilaku individu dalam melakukan suatu pekerjaan karena dalam suatu organisasi terdapat berbagai macam katakteristik yang berbeda-beda antar karyawan yang satu dengan yang lain. Seorang pemimpin jika mengi-nginkan organisasi yang dipimpinnya dapat mencapai tujuan yang diinginkan maka perlu mengetahui perilaku individu (karyawan) yang ada dalam organisasi tersebut agar pemimpin dapat mengarahkan dan memotivasi karyawan dengan mudah untuk mencapai kinerja yang tinggi atau prestasi kerja.

Motivasi membangun hipotesis yang digunakan untuk menjelaskan inisiasi, arah, intensitas, dan perilaku yang diarahkan pada tujuan, seperti kebutuhan untuk berprestasi, kebutuhan untuk berafisiliasi, insentif (penghargaan atau hukuman), kebiasaan, perbedaan, dan rasa ingin tahu (Good dan Brophy, 1990). Robbins dan Jugde (2008) mengartikan motivasi sebagai proses yang menjelaskan intensitas, arah, dan ketekunan seorang individu untuk mencapai tujuannya. Menurut Wahjosumidjo (2003) dan Adeoye dan Elegunde (2014) bahwa motivasi dibagi menjadi dua yaitu motivasi dari dalam diri seseorang itu sendiri (motivasi intrinsik) dan motivasi dari 
luar diri (motivasi ekstrinsik). Motivasi merupakan faktor penting dalam meningkatkan kinerja karyawan. Karyawan yang termotivasi adalah mereka yang melaksanakan upaya substansial dalam rangka mencapai kinerja dan tujuan organisasi.

Kinerja merupakan elemen normatif yang mencerminkan perilaku tenaga penjual, dan sesuai atau tidak sesuai dengan tujuan perusahaan. Kinerja menurut Dessler (2006) merupakan prestasi kerja, yakni perbandingan antara hasil kerja yang dapat dilihat secara nyata dengan standar kerja yang telah ditetapkan organisasi. Spiro dan Weitz menjelaskan bahwa kinerja penjualan selalu dapat dipandang sebagai hasil dari dijalankannya sebuah peran strategik tertentu, yang bagi seorang tenaga penjualan, kinerja itu dihasilkan sebagai akibat dari keagresifan salesforce mendekati dan melayani dengan baik customernya (Mulatsih, 2011). Baldauf, et al. (2001) mendefinisikan kinerja tenaga penjual sebagai suatu bentuk evaluasi dari kontribusi-kontribusi tenaga penjual untuk mencapai tujuan-tujuan organisasi. Kinerja yang telah dilaksanakan harus dievaluasi apakah sudah sesuai dengan tingkat/standar yang diharapkan. Oleh karena itu untuk menjaga stabilitas kerja sumber daya manusia perlu melakukan evaluasi kerja. Hal ini harus selalu dilakukan secara berkala mengingat bahwa produktivitas kerja setiap orang memiliki kemungkinan untuk menurun karena banyak faktor. Beberapa indikator dalam melakukan penilaian terhadap kinerja antara lain kemapuan konseptual, pengetahuan teknis tentang pekerjaannya, kemampuan hubungan interpersonal yang baik, dan tercapainya target penjualan.

Hipotesis diartikan sebagai dugaan pemecahan masalah yang bersifat sementara. Hipotesis pada penelitian ini yaitu sebagai berikut.

H1: Kompensasi berpengaruh positif terhadap motivasi.

H2: Karakteristik tenaga pemasar berpengaruh positif terhadap motivasi.

H3: Gaya kepemimpinan berpengaruh positif terhadap motivasi.

H4: Motivasi berpengaruh positif terhadap kinerja tenaga pemasar.

H5: Kompensasi berpengaruh positif terhadap kinerja tenaga pemasar.

H6: Karakteristik tenaga pemasar berpengaruh positif terhadap kinerja tenaga pemasar.
H7: Gaya kepemimpinan berpengaruh positif terhadap kinerja tenaga pemasar.

H8: Kompensasi berpengaruh terhadap kinerja tenaga pemasar melalui motivasi

H9: Gaya kepemimpinan berpengaruh terhadap kinerja tenaga pemasar melalui motivasi.

H10: Karakteristik tenaga pemasar berpengaruh terhadap kinerja tenaga pemasar melalui motivasi.

\section{METODE}

Penelitian ini merupakan penelitian deskriptif kuantitatif. Populasi penelitian ini adalah seluruh tenaga pemasar di PT Bank Rakyat Indonesia (Persero) Tbk. Cabang Jombang berjumlah 170 orang tenaga pemasar, yang terdiri dari 136 tenaga pemasar mikro dan 34 tenaga pemasar ritel. Sampel yang diambil dalam penelitian sejumlah 136 tenaga pemasar mikro. Alasan pemilihan sampel dari tenaga pemasar mikro karena kontribusi kinerja keuangan mikro pada PT. Bank Rakyat Indonesia (Persero) Tbk. Cabang Jombang lebih besar dari pada kinerja keuangan ritel. Teknik pengumpulan data menggunakan kuesioner atau angket, wawancara dan dokumentasi. Metode analisis yang digunakan dalam penelitian ini menggunakan Structural Equation Modelling (SEM). Pengujian hipotesis dilakukan dengan menggunakan program AMOS versi 22.0 untuk menganalisis hubungan kausalitas dalam model struktural yang diusulkan dan untuk menganalisis mediasi mengunakan uji tes Sobel (Sobel Test).

\section{HASIL DAN PEMBAHASAN}

Pada penelitian ini data responden dideskripsikan melalui jenis kelamin, usia, strata akademis, job grade, dan status pekerjaan. Jumlah responden berjenis kelamin laki-laki sebanyak 99 orang atau $73 \%$, dan 37 orang atau $27 \%$ reponden berjenis kelamin wanita. Jumlah responden berdasarkan usia diketahui kelompok usia paling dominan adalah usia 20-30 tahun sebanyak 85 orang (63\%), sedangkan kelompok usia terkecil yaitu pada usia > 50 tahun sebanyak 1 orang (1\%). Banyaknya responden berdasarkan kelompok job grade (JG) yaitu paling dominan adalah pada JG 3 sebanyak 92 orang (68\%), sedangkan kelompok job grade terkecil adalah > JG 5 dengan presentase $0 \%$. Berdasarkan status pekerjaan, status pekerjaan paling dominan adalah pekerja tetap sebanyak 
106 orang (78\%), sedangkan status pekerjaan terkecil yaitu pekerja kontrak sebanyak 30 orang $(22 \%)$.

Hasil analisis AMOS dalam penelitian ini adalah uji validitas dan reliabilitas, uji asumsi model, dan analisis uji konfirmasi antar kontruk full model. Hasil pengujian validitas menggunakan Confirmatory Factor Analisys (CFA) menyatakan semua indikator dari variabel yang diteliti yaitu kompensasi, gaya kepemimpinan, karakteristik individu, dan motivasi mempunyai nilai factor loading $\geq 0,5$ sehingga semua indikator dari variabel tersebut dinyatakan valid. Hasil pengujian realibilitasnya menunjukkan nilai cronbach alpha $>0,7$ dengan kriteria reliabilitas baik. Sedangkan untuk variabel kinerja, dari 11 indikator ada 2 indikator tidak valid karena nilai factor loading $\leq 0,5$ yaitu indikator kelima nilai 0,419 dan indikator kesebelas nilainya 0,422 . Indikator yang tidak valid harus dihilangkan dahulu, kemudian dihitung reliabilitasnya. Hasil pengujian reliabilitas untuk sembilan indikator dari variabel kinerja menunjukkan nilai cronbach alpha $>0,7$ yaitu sebesar 0,877 dengan kriteria reliabilitas baik, sehingga disimpulkan bahwa dari 5 variabel penelitian terdapat 35 indikator dinyatakan valid dan reliabel.

Berdasarkan uji asumsi model yang meliputi asumsi kecakupan sampel yaitu jumlah responden dalam penelitian ini sebanyak 136 responden. Hasil pengujian normalitas data penelitian baik secara univariate nilai-nilai dalam C.R skewness seluruh item memiliki nilai $<$ 2,58 yang berarti bahwa sebaran data terdistribusi normal. Pengujian normalitas secara multivariate menunjukkan nilai C.R kurtosis $10,855>7$, sehingga disimpulkan bahwa secara multivariate data tidak terdistribusi normal.

Hasil analisis modifikasi indeks stuctural equation modeling sebagai berikut.

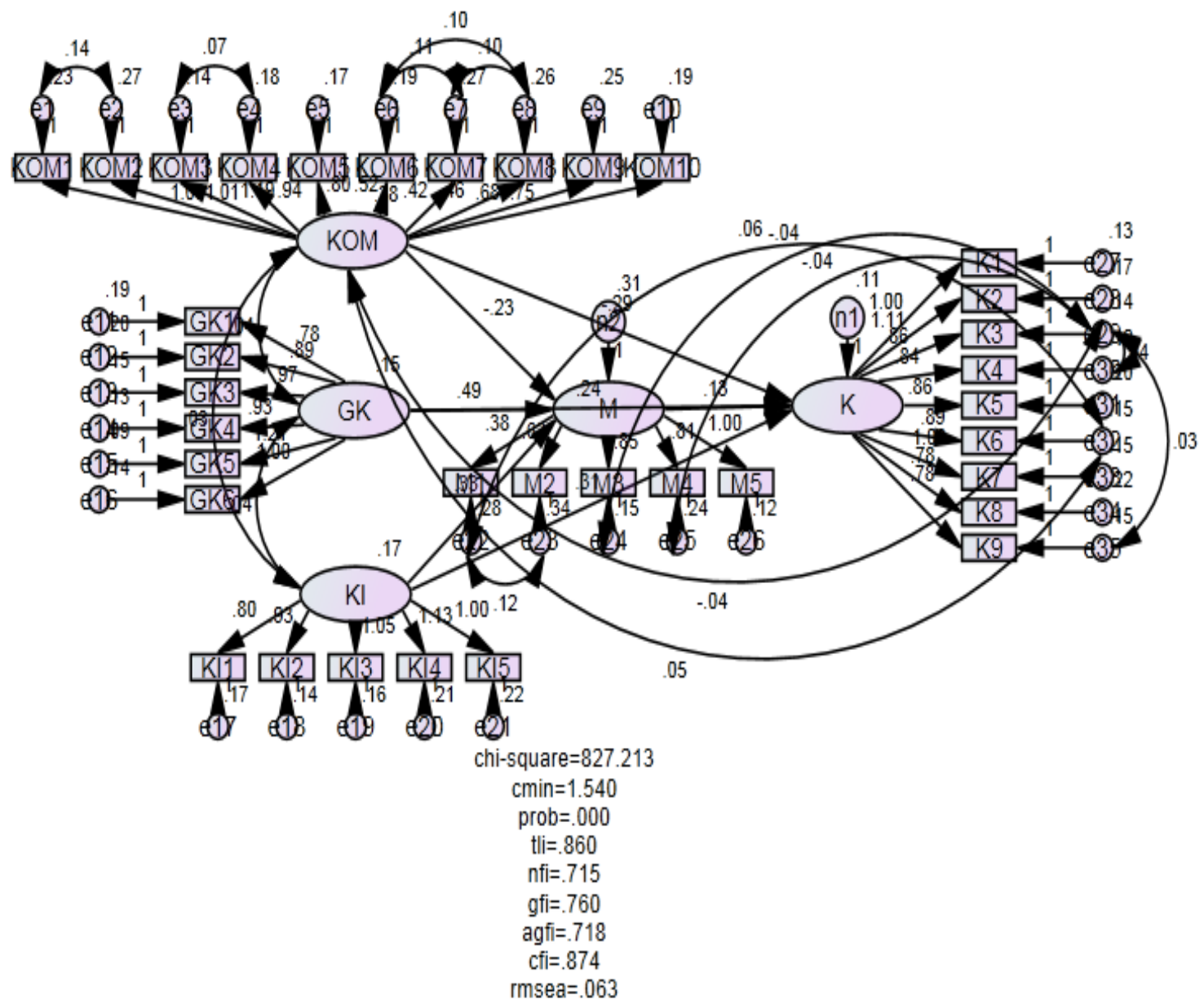

Gambar 1. Modifikasi Model Struktural 
Evaluasi nilai goodness of fit hasil modifikasi di atas dapat dilihat pada tabel 1 di bawah ini.

Tabel 1. Hasil Goodness of Fit Model Modifikasi

\begin{tabular}{llcc}
\hline \multicolumn{1}{c}{ Kriteria } & Hasil & Nilai Kritis & Evaluasi Model \\
\hline Chi-square & 827,213 & Kecil & Baik \\
\hline Cmin/df & 1,540 & $\leq 2,00$ & Baik \\
\hline Probability & 0,000 & $\geq 0,05$ & Tidak fit \\
\hline RMSEA & 0,063 & $\leq 0,08$ & Baik \\
\hline GFI & 0,760 & $\geq 0,90$ & Margin \\
\hline AGFI & 0,718 & $\geq 0,90$ & Margin \\
\hline TLI & 0,860 & $\geq 0,90$ & Margin \\
\hline CFI & 0,874 & $\geq 0,90$ & Margin \\
\hline
\end{tabular}

Sumber: Data primer yang diolah (2016)

Berdasarkan tabel 1 di atas kriteria goodness of fit hasil modifikasi menunjukkan bahwa dari 8 pengukuran goodness of fit, hanya terdapat 3 pengukuran yang baik atau fit, sedangkan 4 pengukuran margin dan 1 pengukuran tidak fit.

Setelah melakukan analisis terhadap full model struktural, maka diketahui analisa uji nilai C.R bahwa semua variabel yaitu kompensasi, gaya kepemimpinan, karakteristik individu, motivasi dan kinerja tenaga pemasar mempunyai p-value kurang dari 5\% yaitu 0.000 . Oleh karena itu disimpulkan bahwa semua indikator diindikasi membentuk variabel latennya secara signifikan.

Hasil uji hipotesis structural equation modeling dari setiap hubungan antar variabel penelitian yaitu pada tabel 2 berikut:

Tabel 2. Hasil Pengujian Hipotesis

\begin{tabular}{|c|c|c|c|c|c|c|c|}
\hline \multicolumn{3}{|c|}{ Hubungan Variabel } & Estimate & S.E. & C.R. & $\mathrm{P}$ & Keterangan \\
\hline $\mathrm{M}$ & $<---$ & GK & .490 & .164 & 2.989 & .003 & Signifikan \\
\hline $\mathrm{M}$ & $<---$ & KOM & -.235 & .113 & -2.079 & .038 & Signifikan \\
\hline $\bar{M}$ & $<---$ & KI & .331 & .153 & 2.166 & .030 & Signifikan \\
\hline $\mathrm{K}$ & $<---$ & KOM & -.292 & .078 & -3.746 & $* * *$ & Signifikan \\
\hline $\mathrm{K}$ & $<---$ & KI & .309 & .104 & 2.979 & .003 & Signifikan \\
\hline $\mathrm{K}$ & $<---$ & GK & .240 & .108 & 2.225 & .026 & Signifikan \\
\hline $\mathrm{K}$ & $<--$ & $\mathrm{M}$ & .134 & .067 & 1.993 & .046 & Signifikan \\
\hline
\end{tabular}

Sumber: Data primer yang diolah (2016)

Berdasarkan tabel 2 diketahui kompensasi berpengaruh signifikan negatif terhadap motivasi kerja dilihat dari nilai estimate sebesar $-0,235$. Nilai C.R sebesar $-2,079$ dengan nilai probabilitas sebesar $0,038<0,05$ yang berarti semakin tinggi kompensasi maka akan berpengaruh terhadap penurunan motivasi kerja. Karakteristik individu tenaga pemasar berpengaruh signifikan positif terhadap motivasi dengan dengan perolehan nilai estimate sebesar 0,331. Nilai C.R sebesar 2,166 dengan nilai probabilitas sebesar $0,030<0,05$ yang berarti semakin tinggi karakteristik individu tenaga pemasar maka akan berpengaruh terhadap peningkatan motivasi kerja. Gaya kepemimpinan berpengaruh signifikan positif terhadap motivasi dengan perolehan nilai estimate sebesar 0,490. Nilai probabilitas $0,003<0,05$ yang berarti semakin tinggi gaya kepemimpinan maka berpengaruh terhadap peningkatan motivasi kerja. Motivasi berpengaruh signifikan positif terhadap kinerja dengan perolehan nilai estimate sebesar 0,134. nilai probabilitas tersebut $0,046<0,05$ yang berarti semakin tinggi motivasi kerja akan berpengaruh terhadap peningkatan kinerja.

Selanjutnya variabel kompensasi berpengaruh signifikan negatif terhadap kinerja dengan perolehan nilai estimate sebesar -0,292. Hal ini yang berarti bahwa setiap peningkatan kompensasi akan menurunkan kinerja karyawan sebesar $-0,292$. Nilai probabilitas $0,000<0,05$ yang berarti semakin tinggi kompensasi akan berpengaruh terhadap peningkatan kinerja. Hasil analisis variabel karakteristik individu tenaga pemasar berpengaruh signifikan positif 
terhadap kinerja dengan nilai estimate sebesar 0,390 . Nilai probabilitas $0,003<0,05$ yang berarti semakin tinggi karakteristik individu tenaga pemasar maka, akan berpengaruh terhadap peningkatan kinerja. Gaya kepemimpinan berpengaruh signifikan positif terhadap kinerja dengan nilai estimate sebesar
0,240. Nilai probabilitas $0,026<0,05$ yang berarti semakin tinggi gaya kepemimpinan akan berpengaruh terhadap peningkatan kinerja. Pengaruh kompensasi terhadap kinerja melalui motivasi kerja dilakukan menggunakan pengujian Sobel (Sobel Test). Tabel 3 berikut merupakan hasil dari pengujian Sobel Test yaitu:

Tabel 3. Hasil Pengujian Sobel Test Pengaruh Kompensasi Terhadap Kinerja Melalui Motivasi

\begin{tabular}{|c|c|c|c|c|}
\hline Input: & & Test statistic: & Std. Error: & p-value: \\
\hline a -0.235 & Sobel test: & -1.47549303 & 0.02134202 & 0.14008004 \\
\hline b 0.134 & Aroian test: & -1.39744052 & 0.02253405 & 0.16228114 \\
\hline$s_{a} 0.113$ & Goodman test: & -1.56827855 & 0.02007934 & 0.11681614 \\
\hline$s_{b} 0.064$ & Reset all & & Calculate & \\
\hline
\end{tabular}

Hasil pengujian Sobel Test di atas diketahui bahwa motivasi kerja memediasi pengaruh antara kompensasi terhadap kinerja. Hal ini dapat dilihat dari nilai p-value 0.1400 yang lebih besar dari nilai 0.05 ( $\mathrm{p}>0.05$ ). Sedangkan hasil Sobel Test pengaruh gaya kepemimpinan terhadap kinerja melalui motivasi kerja yaitu:

Tabel 4. Hasil Pengujian Sobel Test Pengaruh Gaya Kepemimpinan Terhadap Kinerja Melalui Motivasi

\begin{tabular}{|c|c|c|c|c|}
\hline Input: & & Test statistic: & Std. Error: & p-value: \\
\hline a 0.490 & Sobel test: & 1.71465012 & 0.03829353 & 0.08640939 \\
\hline b 0.134 & Aroian test: & 1.65365763 & 0.03970592 & 0.0981971 \\
\hline$S_{a} 0.164$ & Goodman test: & 1.78293085 & 0.036827 & 0.07459756 \\
\hline$s_{b} 0.064$ & Reset all & & Calculate & \\
\hline
\end{tabular}

Hasil pengujian Sobel Test diketahui bahwa motivasi kerja memediasi pengaruh antara gaya kepemimpinan terhadap kinerja, dilihat dari nilai p-value sebesar 0.086 yang lebih besar dari nilai 0.05 ( $p>0.05)$. Hasil Sobel Test pengaruh karakteristik individu tenaga pemasar terhadap kinerja melalui motivasi yaitu:

Tabel 5. Hasil Pengujian Sobel Test Pengaruh Karakteristik Terhadap Kinerja Melalui Motivasi

\begin{tabular}{|c|c|c|c|c|}
\hline Input: & & Test statistic: & Std. Error: & p-value: \\
\hline a 0.331 & Sobel test: & 1.50452515 & 0.0294804 & 0.1324462 \\
\hline$b \longdiv { 0 . 1 3 4 }$ & Aroian test: & 1.4278227 & 0.03106408 & 0.1533429 \\
\hline$S_{a} 0.153$ & Goodman test: & 1.59508523 & 0.02780666 & 0.11069318 \\
\hline$s_{b} 0.064$ & Reset all & & Calculate & \\
\hline
\end{tabular}

Hasil pengujian Sobel Test diketahui bahwa motivasi kerja memediasi pengaruh antara karakteristik individu tenaga pemasar terhadap kinerja. Berdasarkan nilai $\mathrm{p}$-value yaitu 0.132 yang lebih besar dari nilai 0.05 ( $p>0.05)$.

\section{Hipotesis 1}

Hasil analisis diketahui bahwa kompensasi berpengaruh signifikan negatif terhadap motivasi kerja. Semakin tinggi kompensasi yang diberikan perusahaan maka akan berpengaruh terhadap penurunan motivasi kerja, sehingga hipotesis 1 ditolak. Hasil analisis tidak sejalan dengan pendapat tokoh terdahulu. Mphil et al. (2014) menjelaskan 
tujuan utama dari kompensasi adalah agar karyawan lebih termotivasi dalam melaksanakan pekerjaannya. Pemberian kompensasi sangat penting bagi karyawan, karena besar kecilnya kompensasi akan berpengaruh terhadap motivasi kerja karyawan sehingga dapat meningkatkan kinerjanya. Hasil penelitian ini sejalan dengan penelitian Nwude dan Uduji (2013) yang menyatakan kompensasi berupa gaji, komisi insentif, pembayaran bonus, tunjangan, peluang pengakuan untuk promosi dan kemajuan merupakan faktor utama yang berpengaruh terhadap motivasi dan efektivitas meningkatkan penjualan.

Tingginya kompensasi yang diberikan perusahaan secara tidak langsung akan berpengaruh pada meningkatnya target atau beban kerja. Pemimpin perusahaan terus memotivasi karyawannya untuk bekerja maksimal agar target kerja yang dibebankan tersebut bisa tercapai. Tingginya target kerja terkadang menjadikan pemimpin perusahaan memberikan motivasi lebih pada karyawan. Pemberian motivasi yang terlalu berlebihan justru akan menjadikan karyawan merasa bosan dan menganggap motivasi tersebut hanya suatu paksaan bahkan ancaman dari pimpinan agar terget kerja tercapai sehingga kompensasi yang tinggi bisa diperoleh. Berdasarkan keadaan tersebut sangatlah wajar apabila tingginya kompensasi tidak berpengaruh terhadap peningkatan motivasi kerja. Temuan penelitian ini didukung oleh penelitian Juliningrum dan Sudiro (2013) yang menyatakan kompensasi tidak memiliki pengaruh terhadap motivasi kerja. Kompensasi belum dikondisikan sehingga pegawai tidak mempermasalhkan adanya kompensasi tetapi lebih menitik-beratkan pengharapan terhadap pengakuan diri (aktualisasi diri) dan kepastian pengangkatan pegawai.

\section{Hipotesis 2}

Hasil temuan penelitian ini diketahui bahwa karakteristik individu tenaga pemasar berpengaruh signifikan positif terhadap motivasi kerja. Berdasarkan nilai probabilitas diketahui bahwa semakin tinggi karakteristik individu tenaga pemasar maka akan berpengaruh terhadap peningkatan motivasi kerja. Hal ini berarti bahwa hipotesis 2 diterima. Hasil analisis tersebut sejalan dengan pendapat tokoh terdahulu yang mengungkapkan adanya pengaruh langsung karakteristik individu tenaga pemasar terhadap motivasi kerja. Rahman (2013) mengemukakan bahwa semua karakter individu (keahlian, pendidikan dan pengalaman kerja) menunjang motivasi individu dalam pengembangan karir. Hasil penelitian ini sependapat dengan penelitian Cherian dan Jacob (2013) menyebutan bahwa teori self-efficacy dapat digunakan untuk memotivasi dan meningkatkan kinerja karyawan.

\section{Hipotesis 3}

Berdasarkan hasil analisis diketahui gaya kepemimpinan berpengaruh signifikan positif terhadap motivasi kerja. Nilai probabilitas menunjukkan semakin tinggi gaya kepemimpinan maka akan berpengaruh terhadap peningkatan motivasi kerja. Disimpulkan bahwa gaya kepemimpinan berpengaruh positif terhadap motivasi kerja, dengan demikian hipotesis ketiga terbukti. Hasil penelitian ini sependapat dengan temuan penelitian terdahulu. Kepemimpinan mempe-ngaruhi karyawan untuk secara sukarela mengejar tujuan organisasi (Kreitner dan Kinicki, 2005). Antara gaya kepemimpinan transaksional dan transformasional sama-sama berpengaruh terhadap peningkatan motivasi kerja karyawan. Gaya kepemimpinan transaksional menurut Burn yaitu kepemimpinan yang melakukan transaksi memotivasi para pengikut dengan menyerukan kepentingan pribadi mereka, sedangkan kepemimpinan transformasional merupakan pemimpin visioner yang mengajak sumber daya manusia organisasi bergerak menuju visi yang dimiliki oleh pemimpin (Yukl, 2002).

\section{Hipotesis 4}

Hasil pengujian diketahui motivasi berpengaruh signifikan positif terhadap kinerja. Semakin tinggi motivasi kerja akan berpengaruh terhadap peningkatan kinerja, sehingga hipotesis 4 diterima. Motivasi berhubungan dengan upaya-upaya dalam memenuhi kebutuhan. Semakin besar kebutuhan maka semakin besar pula dorongan untuk melakukan sesuatu. Motivasi dapat memacu karyawan untuk bekerja keras sehingga dapat mencapai tujuan mereka dan berpengaruh pada pencapaian tujuan organisasi. Hasil analisis tersebut sejalan dengan penelitian Pratheepkanth (2011) menyebutkan terdapat hubungan positif antara reward atau penghargaan terhadap motivasi karyawan pada staf perbankan. Indikator motivasi kerja yaitu 
higher performance, consistency achieved, cooperation, willingness of responsibility, challenging work, dan growth in job mengalami peningkatan. Tanaga pemasar yang memiliki motivasi baik atau tinggi akan memperbaiki setiap kesalahan yang dilakukan atau merasa khawatir jika kinerja organisasi berada di bawah tingkat pengharapan. Sebaliknya, tenaga pemasar yang motivasinya kurang baik cenderung tidak memiliki keinginan memperbaiki kesalahannya sehingga kinerja diperoleh tetap rendah.

\section{Hipotesis 5}

Hasil analisis diketahui kompensasi berpengaruh secara signifikan negatif terhadap kinerja. Semakin tinggi kompensasi maka berpengaruh terhadap penurunan kinerja, dengan demikian hipotesis kelima ditolak.Tingginya kompensasi yang diberikan perusahaan akan berpengaruh terhadap peningkatan beban kerja atau target kerja karyawan. Perusahaan akan menuntut tenaga pemasar untuk meningkatkan kinerjanya apabila menginginkan kompensasi yang tinggi. Apabila beban kerja tersebut tidak terpenuhi maka kinerja tenaga pemasar juga akan menurun sehingga kompensasi yang tinggi tidak akan tercapai. Maka sebagai bentuk tanggung jawabnya tenaga pemasar terkadang harus bekerja melebihi jam kerja dan konsekuensinya mendapatkan kompensasi. Tingkat kelelahan bekerja dalam memenuhi target kerja, menyebabkan kompensasi bukan lagi menjadi harapan. Berdasarkan keadaan tersebut, sangatlah wajar jika kompensasi tidak berpengaruh signifikan positif terhadap peningkatan kinerja. Temuan penelitian ini didukung penelitian Firmandari (2014) yang menyatakan variabel bonus tidak berpengaruh terhadap kinerja karyawan. Karyawan menganggap bonus merupakan bagian dari pekerjaan rutin sebagai bentuk konsekuensi dalam menyelesaikan pekerjaan. Di sisi lain tingkat kelelahan kerja sebagai tuntutan penyelesaian tanggung jawab, kadang bonus bukan lagi menjadi harapan. Karyawan akan lebih merasa senang jika bisa pulang tepat waktu untuk bisa bertemu dengan keluarganya. Hasil penelitian Riansari, dkk. (2012) juga mendukung penelitian ini yang menyebutkan tidak terdapat pengaruh langsung yang signifikan antara kompensasi terhadap kinerja karyawan. Karyawan menilai rendah pada indikator upah, gaji, dan tunjangan. Pihak manajerial perlu menyesuaikan upah, gaji maupun tunjangan yang diberikan agar karyawan dapat meningkatan kinerjanya.

\section{Hipotesis 6}

Hasil pengujian diketahui karakteristik individu tenaga pemasar berpengaruh signifikan positif terhadap kinerja. Berdasarkan Semakin tinggi karakteristik individu tenaga pemasar maka, akan berpengaruh terhadap peningkatan kinerja, sehingga hipotesis 6 diterima. Karakteristik individu adalah sesuatu yang dimiliki oleh seseorang yang didalamnya terdiri dari demografi karakteristik variabel, kemampuan, dan kepribadian (Robins dan Judge, 2008). Pengaruh karakteristik individu terhadap kinerja tenaga pemasar terjadi karena pegawai bekerja sesuai keahlian, pendidikan dan pengalaman kerja, serta taat pada aturan kerja atau beretika dalam bekerja, Sehingga pegawai mudah menyelesaikan pekerjaannya yang pada akhirnya berdampak pada peningkatan kinerja. Hasil penelitian Hayati (2014) menyatakan bahwa karakteristik individu dan karaktristik tim berpengaruh positif dan signifikan terhadap kinerja tim.

\section{Hipotesis 7}

Hasil analisis diketahui bahwa gaya kepemimpinan berpengaruh signifikan positif terhadap kinerja. Semakin baik gaya kepemimpinan yang dijalankan maka akan berpengaruh terhadap peningkatan kinerja, dengan demikian hipotesis 7 diterima. Gaya kepemimpinan memberikan efek yang dinamis dalam interaksi antara individu dengan organisasi. Menurut pendapat Timothy, et al. (2011) "Leadership style in an organization is one of the factors that play significant role in enhancing or retarding the interest and commitment of the individuals in the organization". Gaya kepemimpinan dalam sebuah organisasi salah satu faktor yang berpengaruh penting dalam meningkatkan atau memperlambat kepentingan dan komitmen individu dalam organisasi. Hasil penelitian Yeh dan Hong (2012) menyatakan gaya kepemimpinan berpengaruh positif dan signifikan terhadap kinerja karyawan. Motivasi dapat menghasilkan sikap positif dari karyawan sehingga meningkatkan kinerja mereka. Gaya kepemimpinan transaksional dan transformasional memiliki hubungan dengan kecerdasan emosional pemimpin dalam memotivasi untuk meningkatkan kinerja. 


\section{Hipotesis 8}

Berdasarkan hasil analisis menggunakan Sobel Test diketahui motivasi kerja memediasi kompensasi terhadap kinerja, sehingga hipotesis 8 diterima. Hasil analisis ini sejalan dengan penelitian Lamalewa, dkk. (2013) menyatakan bahwa kompensasi berpengaruh terhadap kinerja karyawan melalui motivasi kerja karyawan pada Bank di Kota Merauke. Kompensasi bertujuan untuk membantu perusahaan mencapai tujuan keberhasilan strategi perusahaan dan menjamin terciptanya keadilan eksternal dan internal. Pemberian kompensasi sangat penting bagi karyawan, karena besar kecilnya kompensasi merupakan ukuran terhadap prestasi kerja. Negash et al. (2014) berpendapat kompensasi memberikan efek terhadap produktivitas dan kinerja tenaga pemasar. Hasibuan (2009) menyatakan kompensasi yang diterapkan dengan baik akan memberikan motivasi kerja bagi karyawan. Pemberian kompensasi merupakan kebijaksanaan dalam suatu organisasi yang penting dan strategis karena hal ini berhubungan langsung dengan peningkatan semangat kerja. Temuan penelitian ini juga didukung hasil penelitian Firmandari (2014) yang menyatakan variabel gaji dan tunjangan dimoderasi motivasi berpengaruh positif signifikan terhadap kinerja karyawan. Karyawan yang termotivasi dengan besarnya gaji dan tunjangan, akan bekerja dengan sungguh-sungguh serta energik, bersemangat dalam mengerjakan tugas-tugas yang diberikan perusahaan untuk mendapatkan karier yang lebih baik.

\section{Hipotesis 9}

Hasil pengujian Sobel Test diketahui bahwa motivasi kerja memediasi antara gaya kepemimpinan terhadap kinerja. Hal ini berarti hipotesis 9 diterima. Hasil analisis tersebut sejalan dengan pendapat para tokoh terdahulu. Penerapan gaya kepemimpinan yang berbeda akan memiliki pengaruh yang berbeda pula terhadap motivasi. Gaya kepemimpinan transaksional dan transformasional memiliki hubungan dengan kecerdasan emosional pemimpin dalam memotivasi tenaga pemasar untuk meningkatkan kinerja pemasar (Brown, 2014). Penelitian Mondiani (2012) menjelaskan bahwa kepemimpinan transformasional memotivasi bawahan untuk berbuat lebih baik dari apa yang bisa dilakukan, meningkatkan kepercayaan atau keyakinan diri karyawan yang akan berpengaruh terhadap peningkatan kinerja. Seorang pemimpin jika menginginkan organisasi yang dipimpinnya dapat mencapai tujuan yang diinginkan maka perlu mengetahui perilaku individu (karyawan) yang ada dalam organisasi tersebut agar pemimpin dapat mengarahkan dan memotivasi karyawan.

\section{Hipotesis 10}

Pengujian hipotesis ini dengan Sobel Test diketahui bahwa motivasi kerja memediasi karakteristik individu tenaga pemasar terhadap kinerja. Hal ini berarti bahwa hipotesis 10 diterima. Seorang tenaga pemasar harus memiliki karakteristik positif agar pekerjaannya dapat diselesaikan dengan mudah sehingga dapat mencapai kinerja dan prestasi kerja yang tinggi. Secara teoritis karakteristik individual mencakup sejumlah sifat dasar yang melekat pada individu tertentu. Karakteristik atau perilaku individu yang menyebabkan baiknya kinerja seseorang meliputi faktor fisiologis yaitu kemampuan dan keterampilan, faktor psikologis yaitu tanggapan psikologis yang bersangkutan (persepsi, sikap, kepribadian, pendidikan, pengalaman, dan motivasi), dan faktor demografis seperti, umur, jenis kelamin, latar belakang keluarga, dan kelas sosial dan masa kerja. Semua karakter individu (keahlian, pendidikan dan pengalaman kerja) menunjang motivasi dalam pengembangan karir (Rahman, 2013). Motivasi menjadi pendorong melaksanakan kegiatan guna mendapatkan hasil terbaik sehingga akan berpengaruh pada peningkatan kinerja.

\section{KESIMPULAN}

Berdasarkan hasil analisa data dan pembahasan dapat ditarik kesimpulan bahwa kompensasi berpengaruh signifikan negatif terhadap motivasi kerja. Semakin tinggi kompensasi yang diberikan perusahaan maka berpengaruh terhadap penurunan motivasi tenaga pemasar. Hasil temuan kedua diketahui karakteristik individu tenaga pemasar berpengaruh signifikan positif terhadap motivasi kerja. Semakin tinggi karakteristik individu tenaga pemasar maka akan berpengaruh terhadap peningkatan motivasi kerja. Hasil temuan ketiga diketahui gaya kepemimpinan berpengaruh signifikan positif terhadap motivasi kerja. Semakin tinggi gaya kepemimpinan maka berpengaruh terhadap peningkatan motivasi kerja. Hasil temuan keempat diketahui motivasi berpengaruh 
signifikan positif terhadap kinerja. Semakin tinggi motivasi kerja maka akan berpengaruh terhadap peningkatan kinerja. Hasil temuan kelima diketahui kompensasi berpengaruh signifikan negatif terhadap kinerja. Semakin tinggi kompensasi maka akan berpengaruh terhadap penurunan kinerja, dengan demikian hipotesis kelima tidak terbukti. Hasil temuan keenam diketahui karakteristik individu tenaga pemasar berpengaruh signifikan positif terhadap kinerja. Semakin tinggi karakteristik individu tenaga pemasar akan berpengaruh terhadap peningkatan kinerja. Hasil temuan ketujuh diketahui bahwa gaya kepemimpinan berpengaruh signifikan positif terhadap kinerja. Semakin tinggi atau baik gaya kepemimpinan maka akan berpengaruh terhadap peningkatan kinerja. Hasil temuan kedelapan diketahui motivasi kerja memediasi pengaruh antara kompensasi terhadap kinerja. Hasil temuan kesembilan diketahui motivasi kerja tidak memediasi pengaruh antara gaya kepemimpinan terhadap kinerja. Hasil temuan kesepuluh diketahui motivasi kerja memediasi pengaruh antara karakteristik individu tenaga pemasar terhadap kinerja.

\section{DAFTAR PUSTAKA}

Adeoye, A.O. \& Elegunde, A.F. 2014. Compensation Management and Motivation: Cooking Utensils for Organisational Performance. Mediterranean Journal of Social Sciences, Vol. 5, No. 27, pp: 88-97.

Baldauf, A., Cravens, D.W., \& Piercy, N.F. 2001. Examining Business Strategy, Sales Management and Salesperson Antecedents of Sales Organization Effectiveness. Journal of Personal Selling \& Sales Management, Vol. 21, Issue 2, pp: 109-122.

Brown, C. 2014. The Effects of Emotional Intelligence (EI) and Leadership Style on Sales Performance. Economic Insights Trends and Challenges, Vol. 3, No. 3, pp: $1-14$.

Cherian, J., \& Jacob, J. 2013. Impact of Self Efficacy on Motivation and Performance of Employees. International Journal of Business and Management, Vol. 8, No. 14, pp: 80-88.

Dessler, G. 2006. Manajemen Sumber Daya Manusia. Jakarta: Indeks.

Good, T.E. \& Brophy, J.E. 1990. Educational Psychology: A Realistic Approach. New York: Longman.
Gopal, R., \& Chowdhury, R.G. 2014. Leadership Styles and Employee Motivation: an Empirical Investigation in a Leading Oil Company in India. Impact Journals, Vol. 2, Issue 5, pp. 1-10.

Firmandari, N. 2014. Pengaruh Kompensasi Terhadap Kinerja Karyawan dengan Motivasi Kerja sebagai Variabel Moderasi (Studi Pada Bank Syariah Mandiri Kantor Cabang Yogyakarta). Jurnal Ekonomi dan Bisnis Islam, Vol IX, No. 1, pp: 25-34.

Hasibuan, M.S.P. 2009. Manajemen Sumber Daya Manusia. Jakarta: PT. Bumi Aksara.

Juliningrum, E. \& Sudiro, A. 2013. Pengaruh Kompensasi, Budaya Organisasi terhadap Motivasi Kerja dan Kinerja Pegawai. Jurnal Aplikasi Manajemen, Vol. II, No. 4, pp: 665-676.

Kadarisman. 2012. Manajemen Kompensasi. Jakarta: Raja GrafindoPersada.

Kreitner, R., \& Kinicki, A. 2005. Perilaku Organisasi 5 ed. Jakarta: Salemba Empat.

Lamalewa, F., Maupa, H., \& Taba, M.I. 2013. Pengaruh Kompensasi dan Kepuasan Kerja terhadap Kinerja Karyawan melalui Motivasi Kerja pada Bank di Kota Merauke.

Mondiani, T. 2012. Pengaruh Kepemimpinan Transformasional dan Kompensasi terhadap Kinerja Karyawan PT. PLN (Persero) UPJ Semarang. Jurnal Administrasi Bisnis, Vol. 1, No.1, hlm: 4654.

Mphil, A.H., Ramzan, M., Zubair, H.M.K., Ali, G., \& Arslan, M. 2014. Impact of Compensation on Employee Performance (Empirical Evidence from Banking Sector of Pakistan. International Journal of Business and Social Science, Vol. 5, No. 2, pp. 302-309.

Mulatsih, R. 2011. Studi Tentang Kinerja Tenaga Penjualan (Study of Performance of Sales Persons) Kasus Empiris Pada PT. Sinar Niaga Sejahtera Area Distribusi Jawa Tengah. Jurnal Fokus Ekonomi, Vol. 6 No. 1, pp: 19-39.

Murty, W.A., \& Hundiwinarsih, G. 2012. Pengaruh Kompensasi, Motivasi dan Komitmen Organisasional terhadap Kinerja Karyawan Bagian Akuntansi (Studi Kasus Pada Perusahaan Manufaktur di Surabaya). Journal The Indonesian Accounting Review, Vol. 2, No. 2, pp: 215-228.

Negash, R., Zewude, S., \& Megersa, R. 2014.The Effect of Compensation on 
Employees Motivatio: In Jimma University Academic Staff. Basic Research Journal, Vol 3, No. 2, pp. 17-27.

Nwude, E.C., \& Uduji, J.I. 2013. Determinants of Sales force Effectiveness: Financially Based Rewards Versus Nonfinancial Rewards. Research Journal of Finance and Accounting, Vol. 4, No. 1, pp. 160-168.

Rahman, A. 2013. Pengaruh Karakteristik Individu, Motivasi dan Budaya Kerja terhadap Kinerja Pegawai pada Badan Keluarga Berencana dan Pemberdayaan Perempuan Kabupaten Donggala. e-Jurnal Katalogis, Vol. I, No. 2, pp: 77-86.

Robbins, S.P., \& Judge, T.A. 2008. Perilaku Organisasi Edisi 12. Jakarta: Salemba Empat.
Timothy, C.O, Andy, T.O., Victoria, O.A., \& Idowu, A,N. 2011. Effects of Leadership Style on Organizational Performance: A Survey of Selected Small Scale Enterprises in Ikosi-Ketu Council Development Area Of Lagos State, Nigeria. Australian Journal of Business and Management Research, Vol. 1, No. 7, pp. 100-111.

Thoha, M. 2004. Kepemimpinan dalam Manajemen. Jakarta: Raja Grafindo Persada.

Wahjosumidjo. 2003. Kepemimpinan dan Motivasi. Jakarta: Ghalia Indonesia.

Yeh, H. \& Hong, D. 2012.The Mediating Effectof Organizational Commitmenton Leadership Type and Job Performance. The Journal of Human Resource and Adult Learning, Vol. 8, No. 2, hlm.50-59. 